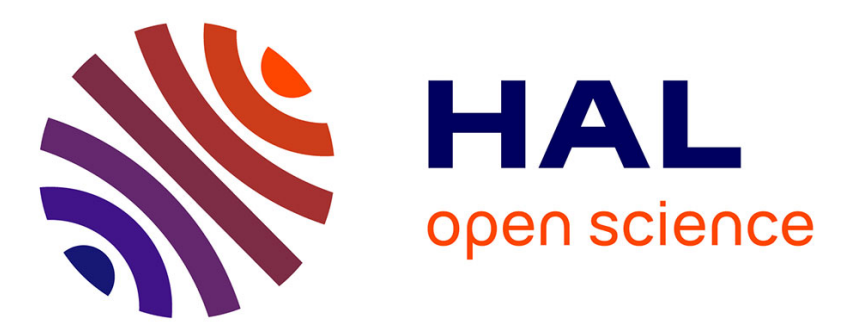

\title{
Kinetics of oxychlorination of magnesium oxide
}

\author{
Ndue Kanari, I. Gaballah, Eric Allain
}

\section{To cite this version:}

Ndue Kanari, I. Gaballah, Eric Allain. Kinetics of oxychlorination of magnesium oxide. Metallurgical and Materials Transactions B, 1999, 30 (6), pp. 1009-1015. 10.1007/s11663-999-0106-6 . hal-01507841

\section{HAL Id: hal-01507841 \\ https://hal.univ-lorraine.fr/hal-01507841}

Submitted on 14 May 2017

HAL is a multi-disciplinary open access archive for the deposit and dissemination of scientific research documents, whether they are published or not. The documents may come from teaching and research institutions in France or abroad, or from public or private research centers.
L'archive ouverte pluridisciplinaire HAL, est destinée au dépôt et à la diffusion de documents scientifiques de niveau recherche, publiés ou non, émanant des établissements d'enseignement et de recherche français ou étrangers, des laboratoires publics ou privés. 


\title{
Kinetics of Oxychlorination of Magnesium Oxide
}

\author{
N. KANARI, I. GABALLAH and E. ALLAIN* \\ Mineral Processing and Environmental Engineering team, \\ LEMa $^{\text {a }}$ CNRS ${ }^{\text {b }}$ UMR 7569, ENSG $^{\mathrm{c}}$, INPL ${ }^{\mathrm{d}}$, BP 40, 54501 Vandœuvre, France \\ * University of Missouri-Rolla, School of Mines and Metallurgy, Center for Pyrometallurgy \\ 210 Fulton Hall, 65401 Rolla, MO, USA
}

The kinetics of oxychlorination of $\mathrm{MgO}$ by $\mathrm{Cl}_{2}+\mathrm{O}_{2}$ were studied in the temperature range of $850{ }^{\circ} \mathrm{C}$ to $1025{ }^{\circ} \mathrm{C}$, using thermogravimetric analysis. The effects of $\mathrm{Cl}_{2} / \mathrm{O}_{2}$ ratio, gas velocity, temperature and partial pressure of reactive gases on the reaction rate were investigated. The oxychlorination process was characterized by an apparent activation energy of about $214 \mathrm{~kJ} / \mathrm{mol}$. The reaction orders with respect to $\mathrm{O}_{2}, \mathrm{Cl}_{2}$ and $\mathrm{Cl}_{2}+\mathrm{O}_{2}$ at $950{ }^{\circ} \mathrm{C}$ were about $-0.37,0.98$, and 0.65 , respectively.

Data concerning oxychlorination of $\mathrm{MgO}, \mathrm{Cr}_{2} \mathrm{O}_{3}$ and $\mathrm{MgCr}_{2} \mathrm{O}_{4}$ contained in chromite were compared. Effectiveness of using oxychlorination to extract iron oxides contained in magnesia was demonstrated.

\footnotetext{
a. Laboratoire Environnement et Minéralurgie, rue du Doyen M. Roubault, BP 40, 54501 Vandœuvre Cedex, France.

b. Centre National de la Recherche Scientifique, 3 rue Michel-Ange, 75794 Paris Cedex, France.

c. École Nationale Supérieure de Géologie, rue du Doyen M. Roubault, BP 40, 54501 Vandœuvre Cedex, France.

d. Institut National Polytechnique de Lorraine, 2 rue de la Forêt de Haye, 54501 Vandœuvre Cedex, France.
} 


\section{INTRODUCTION}

Magnesium is a major element of the chromite ores. It is present in the spinel structure of chromite having the general formula $\left(\mathrm{Fe}^{2+}, \mathrm{Mg}\right)\left(\mathrm{Cr}, \mathrm{Al}, \mathrm{Fe}^{3+}\right)_{2} \mathrm{O}_{4}$ and also in the gangue of chromite concentrates that is essentially composed of magnesium silicates such as olivine and serpentine. [1] Recently, chlorination was studied as a potential method to improve the quality of poor chromite concentrates and for the recovery of specific elements $(\mathrm{Cr}, \mathrm{Fe}, \ldots)$ from chromite concentrates $[1-3]$. The oxychlorination of chromite concentrates by $\mathrm{Cl}_{2}+\mathrm{O}_{2}$ at about $900{ }^{\circ} \mathrm{C}$ allowed almost full extraction of iron and partial recovery of chromium as chromium oxychloride $\left(\mathrm{CrO}_{2} \mathrm{Cl}_{2}\right)$. It was found[4] that the kinetics parameters of the chromite oxychlorination such as activation energies and reaction orders changed with the reaction extents.

Magnesium metal is produced mainly either by the electrolysis of purified $\mathrm{MgCl}_{2}$ from natural brine or by silicothermy. The use of light weight alloys of magnesium by the transport industry allows the production of lighter weight vehicles and consequently reduces the fuel consumption and $\mathrm{CO}_{2}$ emissions ${ }^{[5]}$. Moreover, magnesium oxide is employed in some applications, such as rubber processing, pharmaceuticals, and electrical insulator uses, which require a highpurity $\mathrm{MgO}^{6}$ ]. The common impurities contained in $\mathrm{MgO}$ are $\mathrm{Fe}, \mathrm{Si}, \mathrm{Ca}$... oxides.

For these reasons, kinetic studies of the reactions of $\mathrm{MgO}, \mathrm{Cr}_{2} \mathrm{O}_{3}, \mathrm{Fe}_{2} \mathrm{O}_{3}$ with $\mathrm{Cl}_{2}+\mathrm{O}_{2}$ were undertaken. This paper focused on the oxychlorination kinetics of magnesium oxide in isothermal conditions using thermogravimetric analysis 'TGA'.

No studies concerning the oxychlorination of magnesium oxide were found in the literature. Most of investigations were devoted to the thermodynamical and kinetics aspects of the reactions of $\mathrm{MgO}$ with $\mathrm{Cl}_{2}, \mathrm{Cl}_{2}+\mathrm{C}, \mathrm{HCl}$, and $\mathrm{HCl}+\mathrm{C}$ and they were summarized in Reference [7].

\section{MATERIALS AND EXPERIMENTAL PROCEDURE}

The sample used in this study was $\mathrm{MgO}$ powder having a purity of 98 pct and supplied by PROLABO (Paris, France). Results of Scanning Electron Microscopy (SEM) and X-ray diffraction (XRD) analyses of the magnesium oxide sample are showed in Figure 1. The main identified phase was $\mathrm{MgO}$.

The TGA tests for the oxychlorination of $\mathrm{MgO}$ were performed using $40 \mathrm{mg}$ of sample in a vertical experimental set-up schematized previously[7]. Its main unit was a CAHN 1000 microbalance having a sensitivity of $10 \mu \mathrm{g}$. The oxychlorination gas mixture composed of $\mathrm{Cl}_{2}+\mathrm{O}_{2}$ was purified through $\mathrm{H}_{2} \mathrm{SO}_{4}$ and $\mathrm{CaCl}_{2}$ columns before its introduction in the reactor. The sample was homogeneously distributed in the quartz crucible having a section of about $0.5 \mathrm{~cm}^{2}$. This crucible was hooked to the balance using quartz rods. The sample was preheated in nitrogen atmosphere up to the desired temperature before the introduction of the chlorinating gas mixture. Exhaust gases were purified from chlorine excess by $\mathrm{NaOH}$ solution before their release to the atmosphere. 


\section{RESULTS}

A. Effect of $\mathrm{Cl}_{2} /\left(\mathrm{Cl}_{2}+\mathrm{O}_{2}\right)$ ratio on the oxychlorination of $\mathrm{MgO}$.

The chlorination of $\mathrm{MgO}$ by $\mathrm{Cl}_{2}$ can be represented by Eq. [1]. The melting and boiling points of produced magnesium chloride are $714{ }^{\circ} \mathrm{C}$ and $1412{ }^{\circ} \mathrm{C}$, respectively[8]. As the TGA technique was used to measure the reaction rate, it was mandatory to insure that the rate of $\mathrm{MgCl}_{2}$ volatilization was higher than that of its formation. One possible way to decrease the reaction rate of $\mathrm{MgO}$ with chlorine is to increase the partial pressure of oxygen in the system. Thus, a series of experiments was performed at $950{ }^{\circ} \mathrm{C}$, using a $\mathrm{Cl}_{2}+\mathrm{O}_{2}$ gas mixture having a molar ratio of $\mathrm{Cl}_{2} /\left(\mathrm{Cl}_{2}+\mathrm{O}_{2}\right)$ varying from 0.33 to 1.00 . Figure 2 shows the evolution of the percentage weight loss (pct WL) of magnesium oxide versus time during its oxychlorination using the conditions mentioned above. Only weight losses were observed when using gas mixtures containing less than 90 pct of $\mathrm{Cl}_{2}$. A weight gain followed by a weight loss was recorded when the chlorine content in the gas mixture was higher than 90 pct. This last result indicates that the volatilization rate of magnesium chloride was lower than that of $\mathrm{MgO}$ chlorination and consequently the overall reaction rate was probably controlled by the $\mathrm{MgCl}_{2}$ volatilization rate. For this reason, the kinetics parameters of $\mathrm{MgO}$ oxychlorination were studied using the $\mathrm{Cl}_{2}+\mathrm{O}_{2}$ gas mixtures having a chlorine content lower or equal to 80 pct. In these conditions the observed weight loss was a direct measure of the extent of the overall oxychlorination reaction.

$$
\mathrm{MgO}+\mathrm{Cl}_{2} \rightarrow \mathrm{MgCl}_{2}+1 / 2 \quad \mathrm{O}_{2}
$$

\section{B. Effect of gas flow rate}

In order to determine the intrinsic parameters of the gas-solid reactions, it was necessary to minimize the effect of external mass transfer phenomena [9]. This can be achieved by using a high gas velocity of reactive gases that don't affect the reaction rate. To determine the optimum gas velocity on the oxychlorination rate of $\mathrm{MgO}$, isothermal tests were conducted at $950{ }^{\circ} \mathrm{C}$, using gas mixtures having a linear velocity ' $\mathrm{V}_{\mathrm{g}}$ ' ranging from 12 to $62 \mathrm{~cm} / \mathrm{min}$. Figure 3 gives the evolution of the oxychlorination rate as a function of the gas velocity. The reaction rate increases with the gas velocity up to $\mathrm{V}_{\mathrm{g}} \approx 40 \mathrm{~cm} / \mathrm{min}$. Beyond this value, the rate of oxychlorination was independent of the gas velocity. Therefore, the gas velocity was kept constant and equal to $50 \mathrm{~cm} / \mathrm{min}$ to study the effect of the other parameters on the oxychlorination rate of $\mathrm{MgO}$.

\section{Effect of temperature}

The temperature effect on $\mathrm{MgO}$ oxychlorination was studied between $850{ }^{\circ} \mathrm{C}$ and $1025{ }^{\circ} \mathrm{C}$, using isothermal conditions. An oxychlorinating gas mixture of $\mathrm{Cl}_{2}+\mathrm{O}_{2}$ having a molar ratio $\mathrm{Cl}_{2} / \mathrm{O}_{2}$ $=4$ was used. Figure 4 gives the evolution of pct WL as a function of time for different temperatures. At $850{ }^{\circ} \mathrm{C}$, more than 24 hours were required to reach a reaction extent $\mathrm{X}^{*}$ of about 0.8 , while the same reaction extent was achieved at $1025^{\circ} \mathrm{C}$ for a reaction time of about 1 hour.

\footnotetext{
${ }^{*} \mathrm{X}=$ weight of the reacted fraction/ initial weight
} 
The data of Figure 4 were used to determine the effect of temperature on the reaction rate for a reaction extent between 0.05 and 0.40 . Figure 5 gives the results in an Arrhenius plot. The apparent activation energy ' $\mathrm{E}_{\mathrm{a}}$ ' of $\mathrm{MgO}$ oxychlorination was about $214 \mathrm{~kJ} / \mathrm{mol}$. On the other hand, it was observed that the value of the apparent activation energy remained almost constant for reaction extents equal to or lower than 0.70. Such a high value suggests that the overall rate of $\mathrm{MgO}$ oxychlorination could be controlled by the rate of the chemical reaction.

Different mathematical equations $[9,10]$ were tested to fit the experimental data obtained at different temperatures. Best fitting was obtained using Eq. [2] to describe the evolution of $\mathrm{X}$ versus time for data of Figure 4. Figure 6 gives curves obtained by fitting the chlorination data $(0 \leq \mathrm{X} \leq$ 0.7) of $\mathrm{MgO}$ using this equation for temperatures between $850{ }^{\circ} \mathrm{C}$ and $1025^{\circ} \mathrm{C}$. The correlation coefficient of linearized data was higher than 0.998 .

$$
1-(1-\mathrm{X})^{1 / 2} \quad=\quad \mathrm{kt}
$$

where $\mathrm{k}$ is a constant and $\mathrm{t}$ is chlorination time.

\section{Effect of partial pressures of the reactive gases}

The effects of partial pressure of $\mathrm{Cl}_{2}+\mathrm{O}_{2}, \mathrm{Cl}_{2}$ and $\mathrm{O}_{2}$ were determined in isothermal conditions in order to evaluate the apparent reaction orders with respect to these gases. The partial orders with respect to the reagents could be equal to the stoichiometric coefficients of the reaction only in the case of elemental reactions. For complex reactions the reaction orders differ from these stoichiometric coefficients. They are obtained experimentally and they may be integer, improper fraction, nil, positive or negative numbers ${ }^{[11]}$.

\section{Effect of partial pressure of $\mathrm{Cl}_{2}+\mathrm{O}_{2}$ gas mixture}

The effect of partial pressure of $\mathrm{Cl}_{2}+\mathrm{O}_{2}$ ranging from 0.25 to $1.00 \mathrm{~atm}$ was studied at 950 ${ }^{\circ} \mathrm{C}$ using a $\mathrm{Cl}_{2}+\mathrm{O}_{2}+\mathrm{N}_{2}$ gas mixture having a constant $\mathrm{Cl}_{2} / \mathrm{O}_{2}$ ratio equal to 4 . This ratio was chosen because it was the optimum value for the selective oxychlorination of the chromite concentrate[1-3]. Its use in this case facilitates the comparison of kinetic data of $\mathrm{MgO}$ oxychlorination with those of chromite concentrate. Figure 7 (a) shows the evolution of pct WL as a function of time whilst the relationship between the reaction rate $(0.05 \leq \mathrm{X} \leq 0.40)$ and $\mathrm{P}\left(\mathrm{Cl}_{2}+\mathrm{O}_{2}\right)$ is illustrated in Figure 7 (b). An apparent reaction order with respect to $\mathrm{Cl}_{2}+\mathrm{O}_{2}$ of about 0.65 was deduced from this plot.

\section{Effect of partial pressure of chlorine}

This effect was also studied at $950{ }^{\circ} \mathrm{C}$ keeping the oxygen partial pressure constant and equal to 0.33 atm while varying the chlorine partial pressure from 0.20 to 0.67 atm. Nitrogen was used as a dilution gas and the total gas velocity was about $50 \mathrm{~cm} / \mathrm{min}$. The obtained isotherms were plotted in Figure 8 (a), showing the evolution of pct WL versus time. Figure 8 (b) indicates that the reaction rate was almost proportional to $\mathrm{PCl}_{2}$ since the apparent reaction order with respect to chlorine is close to one. On the other hand, ${ }^{\mathrm{n}} \mathrm{Cl}_{2}$ was higher than ${ }^{\mathrm{n}}\left(\mathrm{Cl}_{2}+\mathrm{O}_{2}\right)$ (Figure $7 \mathrm{~b}$ and $8 \mathrm{~b}$ ). 


\section{Effect of partial pressure of oxygen}

Having determined the effects of $\mathrm{Cl}_{2}+\mathrm{O}_{2}$ and $\mathrm{Cl}_{2}$ partial pressures on the reaction rate it was worthwhile to examine the influence of oxygen partial pressure. The tests were carried out at constant chlorine partial pressure $(0.33 \mathrm{~atm})$ while the partial pressure of $\mathrm{O}_{2}$ was varied from 0.20 to $0.67 \mathrm{~atm}$. Figure 9 (a) traces the evolution of pct WL versus time during the oxychlorination of $\mathrm{MgO}$ at $950{ }^{\circ} \mathrm{C}$. This figure clearly shows that the time required to reach a given reaction extent increases with the augmentation of the partial pressure of $\mathrm{O}_{2}$ in the gas mixture. The evolution of the reaction rate as a function of the oxygen partial pressure is illustrated in Figure 9 (b). The apparent reaction order with respect to oxygen was about -0.37 indicating that the oxygen had a negative effect on the chlorination rate of $\mathrm{MgO}$. This result was expected and agrees with Eq. 1 .

The effects of $\left(\mathrm{Cl}_{2}+\mathrm{O}_{2}\right), \mathrm{Cl}_{2}$ and $\mathrm{O}_{2}$ partial pressures on the oxychlorination rate of $\mathrm{MgO}$ at $950{ }^{\circ} \mathrm{C}$ were compared in Figure 10. The significance of the effects of reactive gases partial pressures, expressed as apparent reaction orders, clearly follows the following sequence $: \mathrm{n}_{\mathrm{Cl}_{2}}>$ $\mathrm{n}_{\left(\mathrm{Cl}_{2}+\mathrm{O}_{2}\right)}>\mathrm{n}_{\mathrm{O}_{2}}$. The apparent reaction order of $\mathrm{n}_{\left(\mathrm{Cl}_{2}+\mathrm{O}_{2}\right)}$ was almost equal to the algebraic sum of those of $\mathrm{nCl}_{2}$ and $\mathrm{n}_{2}$.

\section{DISCUSSION}

As mentioned previously, this study was performed to explain the kinetics of chromite oxychlorination. More details concerning the reaction kinetics of chromite with $\mathrm{Cl}_{2}+\mathrm{O}_{2}$ are available in References 1 through 4 . However, some typical curves of chromite oxychlorination were displayed in Figure 11. It was noticed that the chlorination of chromite was characterized by a rapid reaction rate followed by slow one for reaction extents higher than 0.35 . As an example at $1000{ }^{\circ} \mathrm{C}, 35$ pct of the sample reacted after a reaction time of 15 minutes, while about 12 hours were necessary to reach a reaction extent of 70 pct. This phenomenon was explained by a different reactivity of the two main components of the chromite, $\mathrm{FeCr}_{2} \mathrm{O}_{4}$ and $\mathrm{MgCr}_{2} \mathrm{O}_{4}$, towards oxychlorination gas mixture. The apparent activation energy for reaction extents higher than 0.40 was calculated and corresponds to the oxychlorination of $\mathrm{MgCr}_{2} \mathrm{O}_{4}{ }^{[4]}$.

Figure 12 shows the Arrhenius plots for the oxychlorination of $\mathrm{MgO}, \mathrm{Cr}_{2} \mathrm{O}_{3}$ and $\mathrm{MgCr}_{2} \mathrm{O}_{4}$ contained in the chromite. The values of $\mathrm{E}_{\mathrm{a}}$ were about 214, 46 and $262 \mathrm{~kJ} / \mathrm{mol}$ for oxychlorination of $\mathrm{MgO}, \mathrm{Cr}_{2} \mathrm{O}_{3}$, and $\mathrm{MgCr}_{2} \mathrm{O}_{4}$, respectively. The oxychlorination apparent activation energy of $\mathrm{MgCr}_{2} \mathrm{O}_{4}$ is comparable to that of $\mathrm{MgO}$ oxychlorination.

To confirm that the kinetics parameters of $\mathrm{MgCr}_{2} \mathrm{O}_{4}$ oxychlorination are controlled by the $\mathrm{MgO}$ oxychlorination ones, the effects of the partial pressure of the reactive gases on the reaction rate for the oxychlorination of $\mathrm{MgO}, \mathrm{Cr}_{2} \mathrm{O}_{3}{ }^{[12]}$ and $\mathrm{MgCr}_{2} \mathrm{O}_{4}{ }^{[4]}$ are compared in Table I. The 
reaction order with respect of oxygen had a positive value only for the oxychlorination of $\mathrm{Cr}_{2} \mathrm{O}_{3}$ because it favors the formation of $\mathrm{CrO}_{2} \mathrm{Cl}_{2}$ according to Eq. 3. The apparent reaction orders with respect to $\mathrm{Cl}_{2}+\mathrm{O}_{2}, \mathrm{Cl}_{2}$ and $\mathrm{O}_{2}$ for the oxychlorination of $\mathrm{MgO}$ and $\mathrm{MgCr}_{2} \mathrm{O}_{4}$ contained in chromite were closer, compared with those of $\mathrm{Cr}_{2} \mathrm{O}_{3}$. This suggests that the oxychlorination kinetics of $\mathrm{MgCr}_{2} \mathrm{O}_{4}$ is mostly controlled by the oxychlorination rate of $\mathrm{MgO}$.
$1 / 2$
$\mathrm{Cr}_{2} \mathrm{O}$
$+\mathrm{Cl}_{2}+1 / 4$
$\mathrm{O}_{2} \rightarrow$
$\mathrm{CrO}_{2} \mathrm{Cl}_{2}$

Table I. Comparison of reaction orders with respect to reactive gases of different solids' oxychlorination.

\begin{tabular}{ccccc}
\hline Solids & $\mathrm{n}_{\left(\mathrm{Cl}_{2}+\mathrm{O}_{2}\right)}$ & $\mathrm{n}_{\mathrm{Cl}_{2}}$ & $\mathrm{n}_{\mathrm{O}_{2}}$ & $\mathrm{n}_{\mathrm{Cl}_{2}+} \mathrm{n}_{\mathrm{O}_{2}}$ \\
\hline $\mathrm{Cr}_{2} \mathrm{O}_{3}{ }^{[12]}$ & 1.29 & 1.08 & 0.23 & 1.31 \\
\hline $\mathrm{MgO}$ & 0.65 & 0.98 & -0.37 & 0.61 \\
\hline $\mathrm{MgCr}_{2} \mathrm{O}_{4}[4]$ & 0.43 & 0.64 & -0.25 & 0.39 \\
\hline
\end{tabular}

LeRoy [6] used the low reactivity of magnesium oxide towards chlorine in order to produce high-purity $\mathrm{MgO}$ by selective chlorination of natural calcined magnesite at temperatures ranging from $500{ }^{\circ} \mathrm{C}$ to $800{ }^{\circ} \mathrm{C}$. The impurities such as $\mathrm{CaO}$ and $\mathrm{Fe}_{2} \mathrm{O}_{3}$, contained in the $\mathrm{MgO}$, were converted to chlorides. Ferric chloride was volatilized and calcium chloride was separated by water washing of the residue. The $\mathrm{MgO}$ losses ranged from 0.09 to $6.28 \mathrm{pct}$ according to this author. The following paragraphs describe the possibility to remove iron oxides from $\mathrm{MgO}$ by oxychlorination.

Figure 13 shows the TGA plots of pct WL versus temperature for the $\mathrm{MgO}$ and $\mathrm{Fe}_{2} \mathrm{O}_{3}$ during their treatment in $\mathrm{Cl}_{2}+\mathrm{O}_{2}$ using non isothermal conditions. This figure clearly shows that the reactivity of $\mathrm{Fe}_{2} \mathrm{O}_{3}$ towards an oxychlorinating gas mixture was higher than that of $\mathrm{MgO}$. Almost full chlorination of hematite and volatilization of reaction products were achieved at about $825{ }^{\circ} \mathrm{C}$ while the loss of magnesium oxide was negligible.

More consistent information was obtained during the reaction of these solids with $\mathrm{Cl}_{2}+\mathrm{O}_{2}$ using isothermal tests. These oxides were chlorinated at $850{ }^{\circ} \mathrm{C}$ and $950{ }^{\circ} \mathrm{C}$. Figure 14 illustrates the evolution of pct WL as a function of time. Hematite sample was almost fully chlorinated for a reaction time of about 50 and 10 minutes, at 850 and $950{ }^{\circ} \mathrm{C}$, respectively. Using the same conditions, the weight losses of $\mathrm{MgO}$ were less than 5 pct. In our experimental conditions, $\mathrm{CaO}$ could be chlorinated even in presence of high oxygen partial pressure in the oxychlorinating gas mixture[7] thus leading to the purification of $\mathrm{MgO}$ from its main impurities. 


\section{CONCLUSIONS}

Different kinetics parameters of the $\mathrm{MgO}$ oxychlorination were investigated using the TGA technique. Results indicate that the oxychlorination of magnesium oxide between $850{ }^{\circ} \mathrm{C}$ and $1025{ }^{\circ} \mathrm{C}$ was characterized by an apparent activation energy of about $214 \mathrm{~kJ} / \mathrm{mol}$ indicating that the overall rate of the process was probably controlled by the rate of the chemical reaction.

The reaction rate of $\mathrm{MgO}$ oxychlorination at $950{ }^{\circ} \mathrm{C}$ was almost proportional to the partial pressure of chlorine. The reaction orders, at this temperature, with respect to $\mathrm{Cl}_{2}+\mathrm{O}_{2}$ and $\mathrm{O}_{2}$ were 0.65 and -0.37 , respectively. Negative value of $\mathrm{n}_{\mathrm{O}_{2}}$ is consistent with the nature of the following reaction :

$$
\mathrm{MgO}+\mathrm{Cl}_{2} \quad \rightarrow \quad \mathrm{MgCl}_{2}+1 / 2 \mathrm{O}_{2}
$$

Experimental results also demonstrated that the oxychlorination could be used as an efficient method to purify $\mathrm{MgO}$ from iron oxides. Almost full extraction of iron can be achieved between $850{ }^{\circ} \mathrm{C}$ and $950{ }^{\circ} \mathrm{C}$ with $\mathrm{MgO}$ losses less than 5 pct.

\section{ACKNOWLEDGMENTS}

This work was performed in the frame of contract $\mathrm{N}^{\circ}$ BRE2-CT92-0173 thanks to the financial support of the European Union (DG-XII). The authors thank Dr. H. L. Schmidt for discussion, suggestions and help.

The authors are indebted to Dr. A. Bonazébi, Drs. M. Djona, S. Ivanaj, N. Menad, N. Mirghaffari for discussions and help on different subjects and to Mrs. C. Richard for the technical and administrative support.

\section{REFERENCES}

1. N. Kanari, Ph.D. Thesis, Institut National Polythechnique de Lorraine, Laboratoire Environnement et Mineralurgie, Nancy, France, November 1995, 209 pages.

2. I. Gaballah, Final Report of European Union Contract No BRE2-CT92-0173, Institut National Polythecnique de Lorraine, Laboratoire Environnement et Mineralurgie, Nancy, France, November 1996.

3. N. Kanari and I. Gaballah, Proc. of the $126^{\text {th }}$ TMS Annual Meeting 'EPD Congress 1997', Orlando, FL, Ed. by Mishra B., Pub. by TMS, 1997, 57 - 71.

4. N. Kanari and I. Gaballah, Light Metals 1998, Proc. of the Technical Sessions at the $127^{\text {th }}$ TMS Annual Meeting, San Antonio, TX, Edited by Barry J. Welch, Published by TMS, 1998, 1333 - 1341. 
5. F. H. Froes, D. Eliezer and E. Aghion, The Science, Technology, and Applications of Magnesium, JOM, 1998, 50, $\mathrm{N}^{\circ} 9,30-34$.

6. E. Dastolfo LeRoy Jr., "Production of high purity magnesium oxide by selective chlorination," Light Metals, Warrendale, Pa, 1991, 1181 - 1188.

7. N. Kanari and I. Gaballah, Proc. of the $127^{\text {th }}$ TMS Annual Meeting 'EPD Congress 1998', San Antonio, TX, Edited by Mishra B., Pub. by TMS, 1998, 595 - 609.

8. Anonymous, Handbook of Chemistry and Physics, $74^{\text {th }}$ edition, Editor-in-Chief D.R. Lide, CRC Press, Florida, USA, 1993-94, pp. 4-71 and 6 -69.

9. J. Szekely, J.W. Evans and H.Y. Sohn, in Gas-Solid Reactions, Academic Press, New York, NY. 1976, 68 - 70, 73-88, $109-31$ and $232-35$.

10. I. Gaballah, S. Ivanaj and N. Kanari, Metallurgical and Materials Transactions A, 29A, 1998, 1299 - 1308.

11. G. Pannetier and P. Souchay, in Chimie Générale-Cinétique Chimique, Masson, Paris, 1964, 12 - 14.

12. I. Gaballah and N. Kanari, Proc. of the $126^{\text {th }}$ TMS Annual Meeting 'EPD Congress 1997', Orlando, FL, Ed. by Mishra B., Pub. by TMS, 1997, 35 - 46. 


\title{
Kinetics of Oxychlorination of Magnesium Oxide
}

\author{
N. KANARI, E. ALLAIN*, and I. GABALLAH \\ Mineral Processing and Environmental Engineering team, \\ LEM $^{\mathrm{a}}, \mathrm{CNRS}^{\mathrm{b}} \mathrm{UMR}^{7569}, \mathrm{ENSG}^{\mathrm{c}}$, INPL ${ }^{\mathrm{d}}$, BP 40, 54501 Vandœuvre, France \\ * University of Missouri-Rolla, School of Mines and Metallurgy, Center for Pyrometallurgy \\ 210 Fulton Hall, 65401 Rolla, MO, USA
}

\section{Figure Captions}

Figure 1 : Results of (a) SEM and (b) XRD of the magnesium oxide sample.

Figure 2 : Effect of $\mathrm{Cl}_{2} /\left(\mathrm{Cl}_{2}+\mathrm{O}_{2}\right)$ molar ratio on the $\mathrm{MgO}$ weight loss.

Figure 3 : Effect of gas velocity on the oxychlorination rate of $\mathrm{MgO}$ at $950{ }^{\circ} \mathrm{C}$.

Figure 4 : Isotherms of oxychlorination of magnesium oxide for $(a) \mathrm{T} \leq 925^{\circ} \mathrm{C}$ and $(b) \mathrm{T} \geq 950{ }^{\circ} \mathrm{C}$.

Figure 5 : Arrhenius plot of oxychlorination of $\mathrm{MgO}$ by $\mathrm{Cl}_{2}+\mathrm{O}_{2}$.

Figure 6 : Fitting of oxychlorination data of $\mathrm{MgO}$ using Eq. [2] for $(a) \mathrm{T} \leq 925^{\circ} \mathrm{C}$ and $(b) \mathrm{T} \geq 950{ }^{\circ} \mathrm{C}$.

Figure 7 : Isotherms of oxychlorination of $\mathrm{MgO}(a)$, using various $\mathrm{Cl}_{2}+\mathrm{O}_{2}$ partial pressures and $(b)$ apparent reaction order with respect to $\mathrm{Cl}_{2}+\mathrm{O}_{2}$.

Figure 8 : Isotherms of oxychlorination of $\mathrm{MgO}(a)$, using various $\mathrm{Cl}_{2}$ partial pressures and $(b)$ apparent reaction order with respect to $\mathrm{Cl}_{2}$.

Figure 9 : Isotherms of oxychlorination of $\operatorname{MgO}(a)$, using various $\mathrm{O}_{2}$ partial pressures and $(b)$ apparent reaction order with respect to $\mathrm{O}_{2}$.

Figure 10 : Effect of gases composition on the reaction rate of oxychlorination of $\mathrm{MgO}$.

Figure 11 : Typical isotherm plots for the oxychlorination of chromite.

Figure 12 : Arrhenius plots of $\mathrm{MgO}, \mathrm{Cr}_{2} \mathrm{O}_{3}{ }^{[12]}$ and $\mathrm{MgCr}_{2} \mathrm{O}_{4}{ }^{[4]}$ oxychlorination.

Figure 13 : Non isothermal chlorination of $\mathrm{MgO}$ and $\mathrm{Fe}_{2} \mathrm{O}_{3}$ using $\mathrm{Cl}_{2}+\mathrm{O}_{2}$.

Figure 14 : Oxychlorination of $\mathrm{MgO}$ and $\mathrm{Fe}_{2} \mathrm{O}_{3}$ at $850{ }^{\circ} \mathrm{C}$ and $950{ }^{\circ} \mathrm{C}$. 


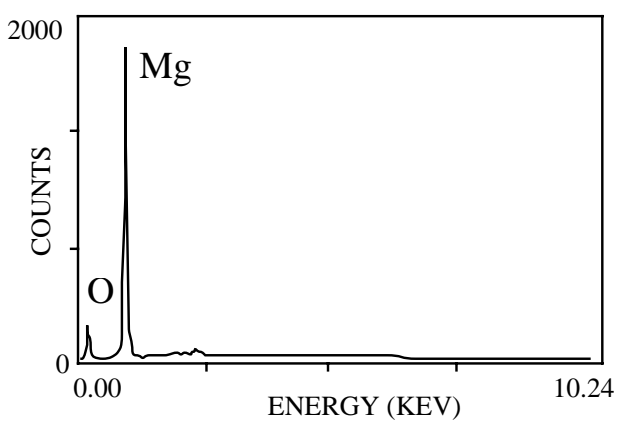

(a)

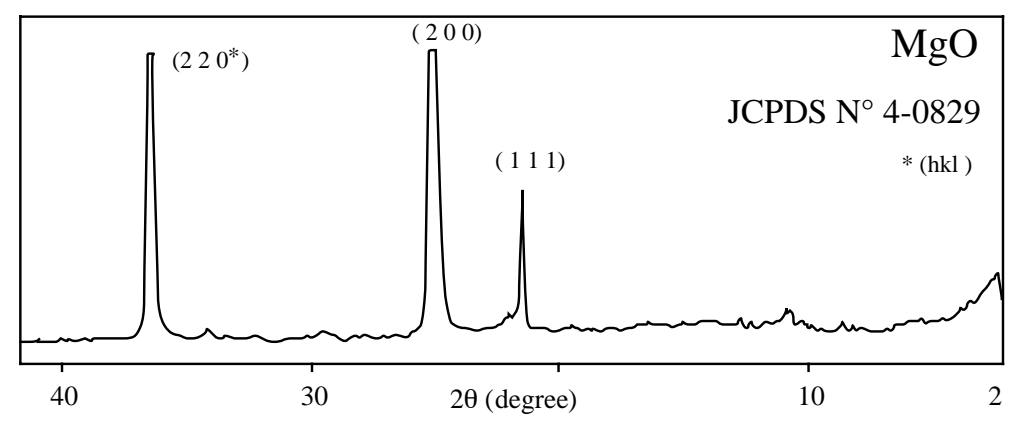

(b)

Fig. 1 : Results of (a) SEM and (b) XRD of the magnesium oxide sample.

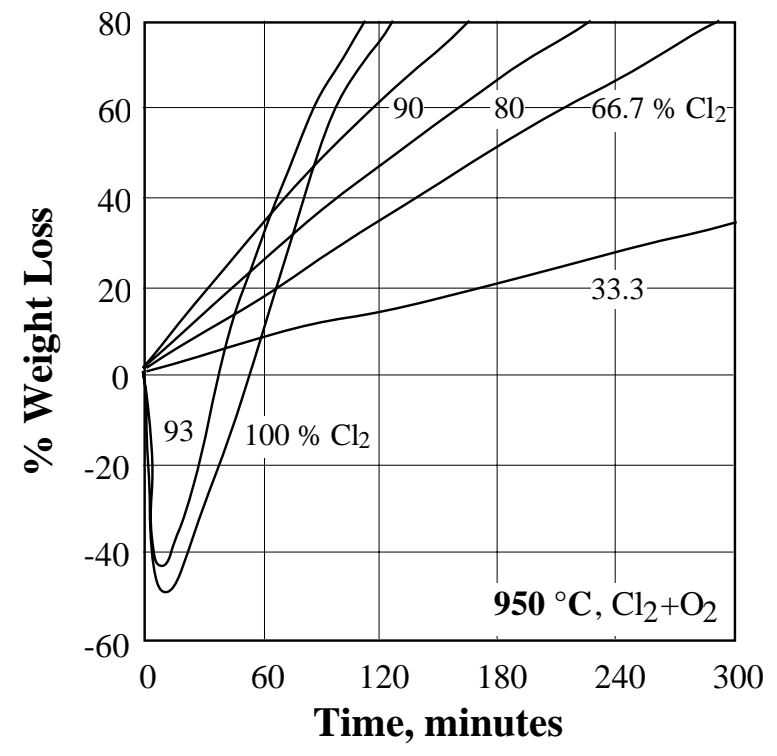

Fig. 2 : Effect of $\mathrm{Cl}_{2} /\left(\mathrm{Cl}_{2}+\mathrm{O}_{2}\right)$ molar ratio on the $\mathrm{MgO}$ weight loss.

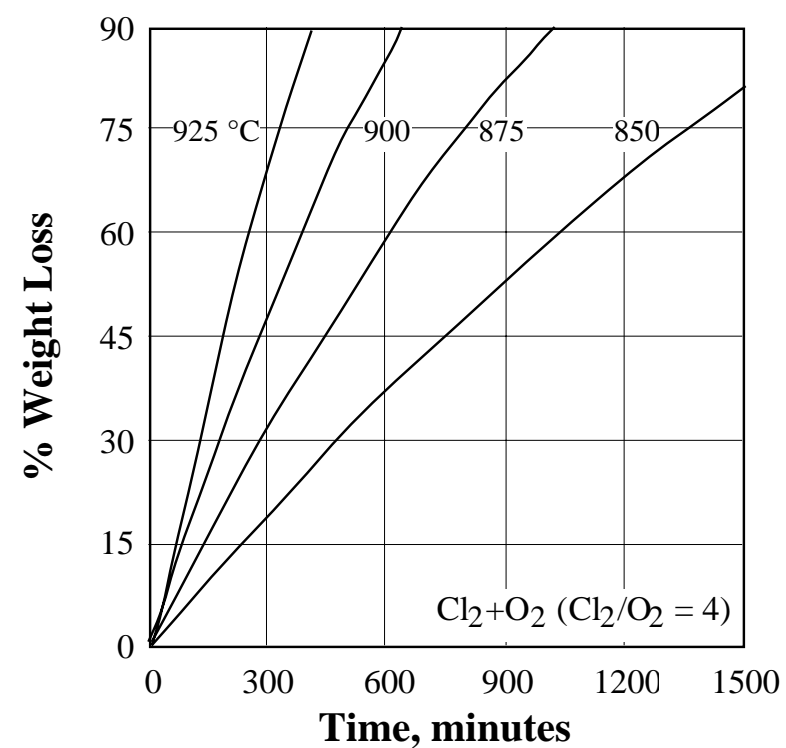

(a)

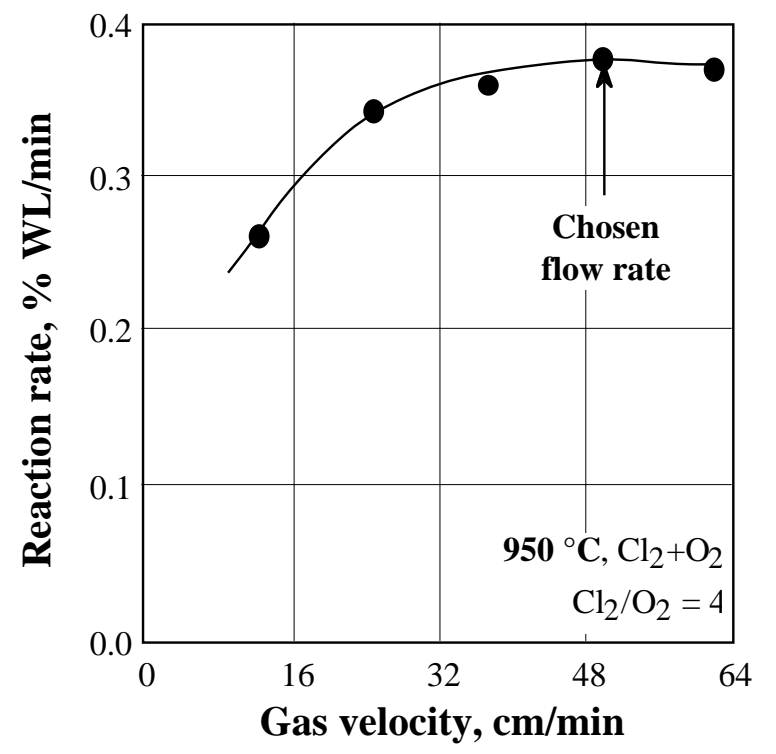

Fig. 3 : Effect of gas velocity on the oxychlorination rate of $\mathrm{MgO}$ at $950^{\circ} \mathrm{C}$

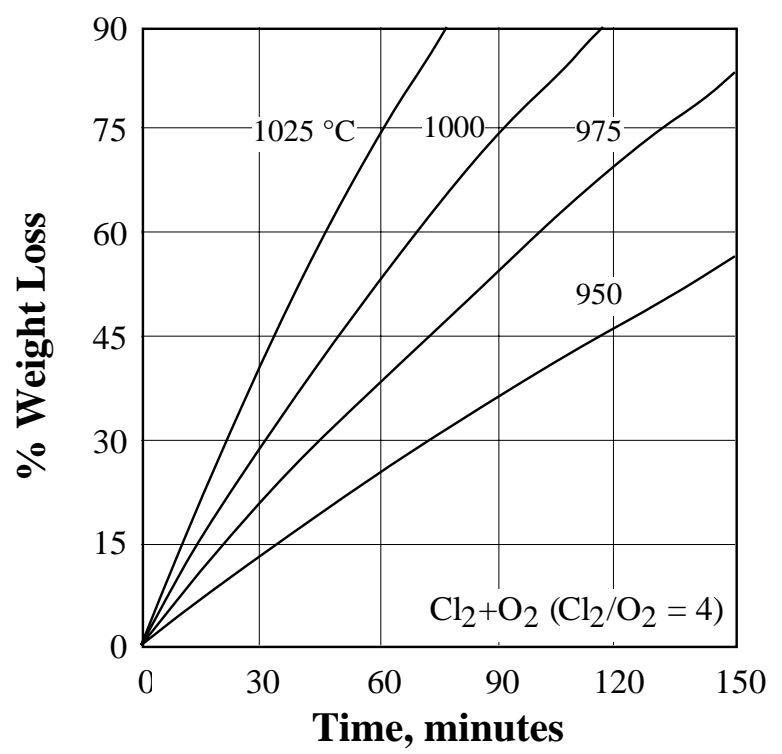

(b)

Fig. 4 : Isotherms of oxychlorination of magnesium oxide for (a) $\mathrm{T} \leq 925^{\circ} \mathrm{C}$ and (b) $\mathrm{T} \geq 950{ }^{\circ} \mathrm{C}$. 


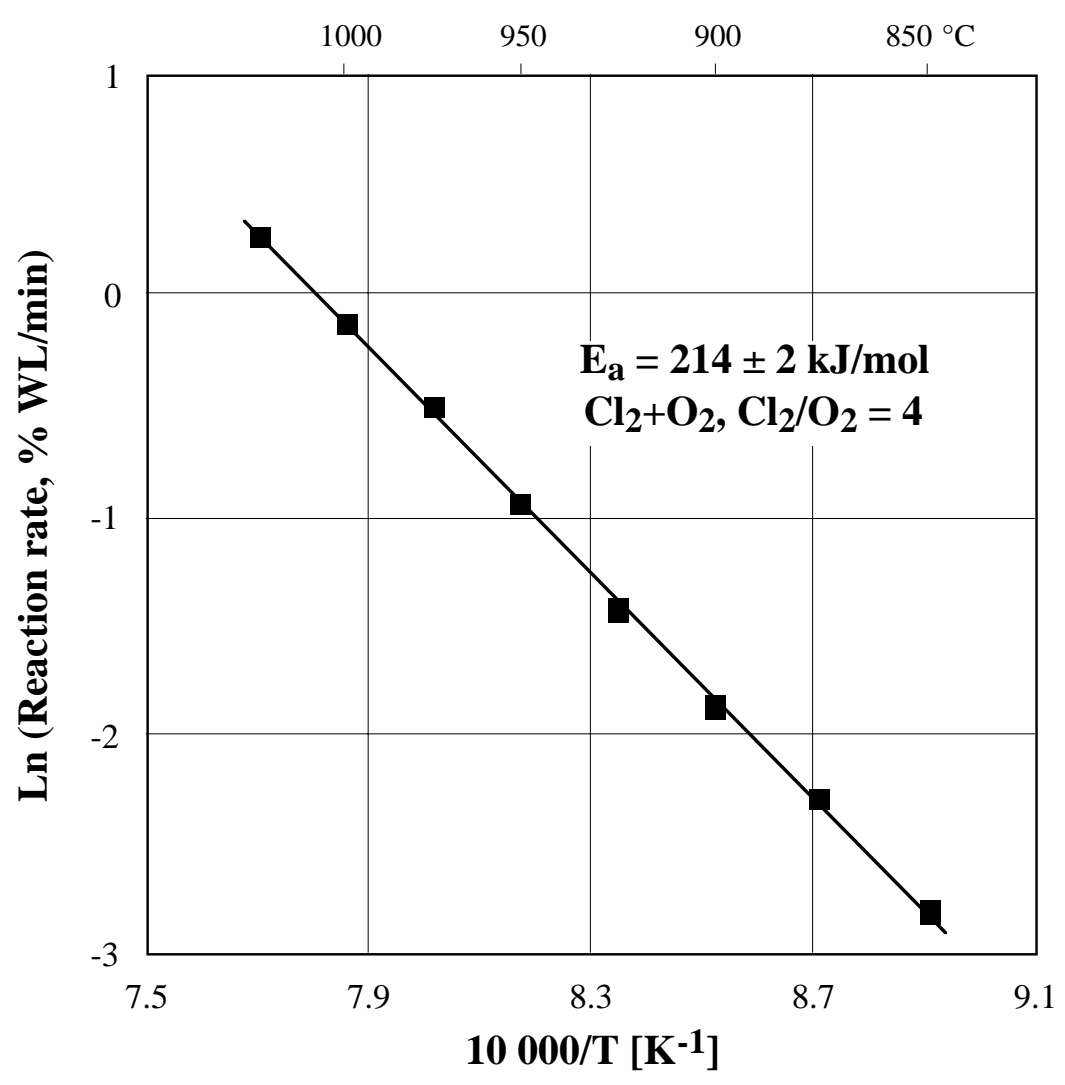

Fig. 5 : Arrhenius plot of oxychlorination of $\mathrm{MgO}$ by $\mathrm{Cl}_{2}+\mathrm{O}_{2}$.

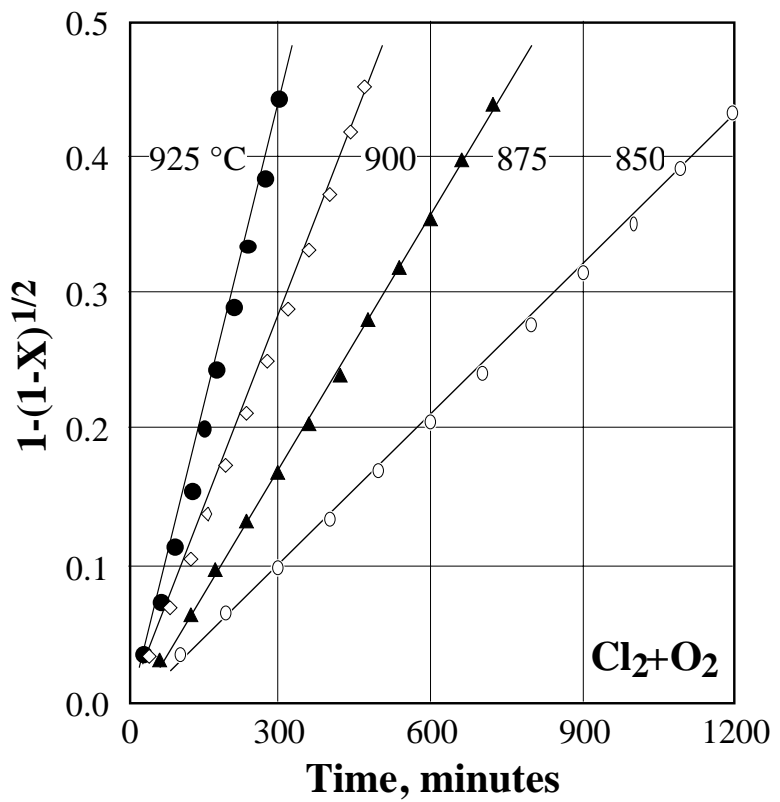

(a)

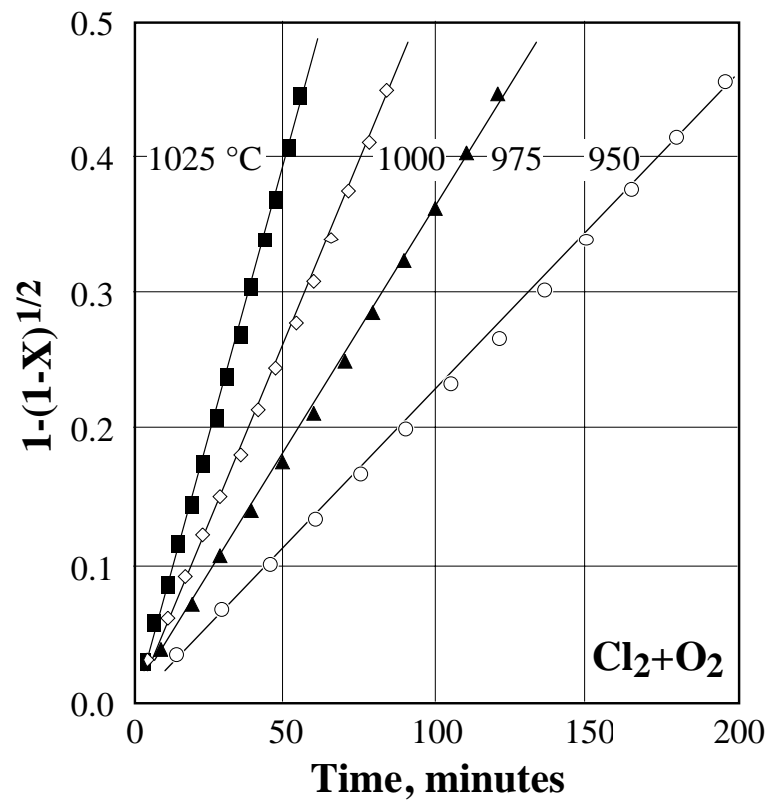

(b)

Fig. 6 : Fitting of oxychlorination data of $\mathrm{MgO}$ using Eq. [2] for (a) $\mathrm{T} \leq 925^{\circ} \mathrm{C}$ and (b) $\mathrm{T} \geq 950{ }^{\circ} \mathrm{C}$. 


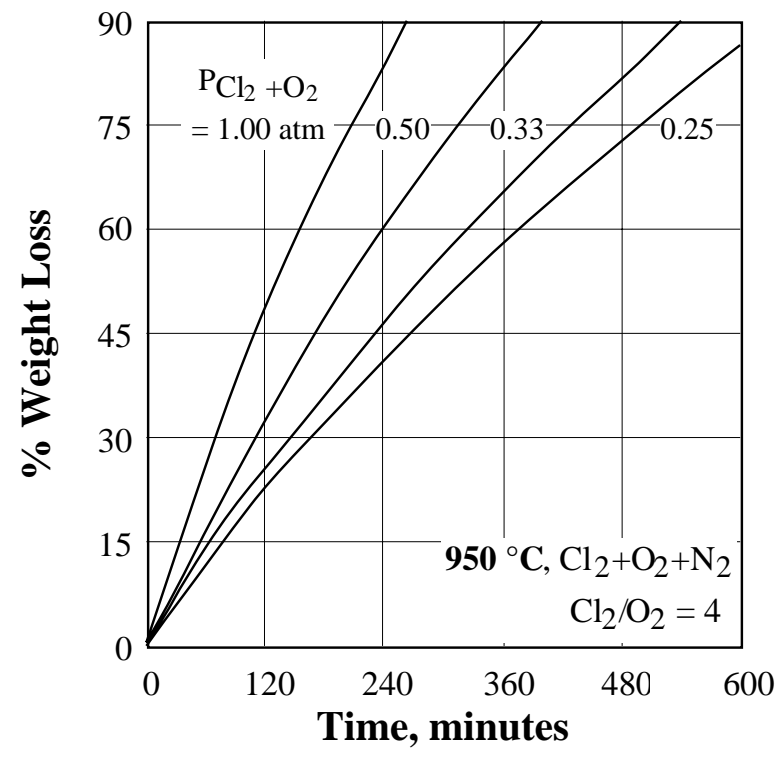

(a)

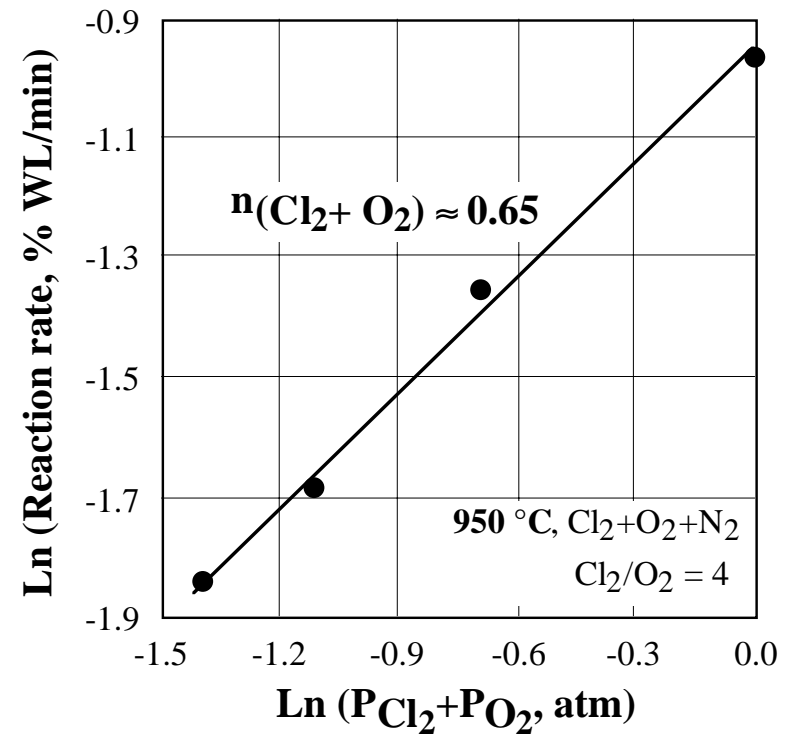

(b)

Fig. 7. Isotherms of oxychlorination of $\mathrm{MgO}$ (a), using various $\mathrm{Cl}_{2}+\mathrm{O}_{2}$ partial pressures and (b) apparent reaction order with respect to $\mathrm{Cl}_{2}+\mathrm{O}_{2}$.

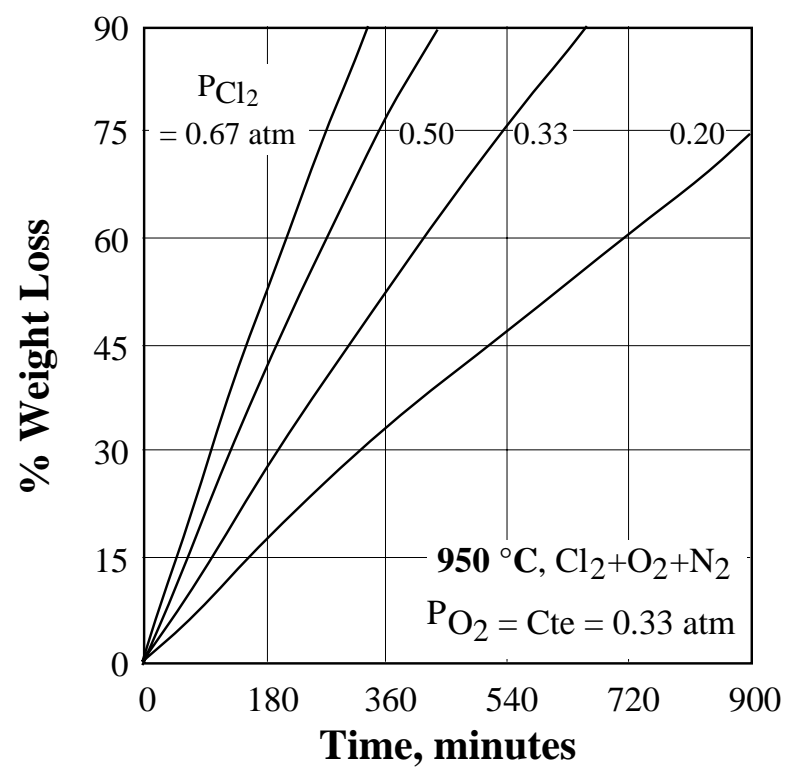

(a)

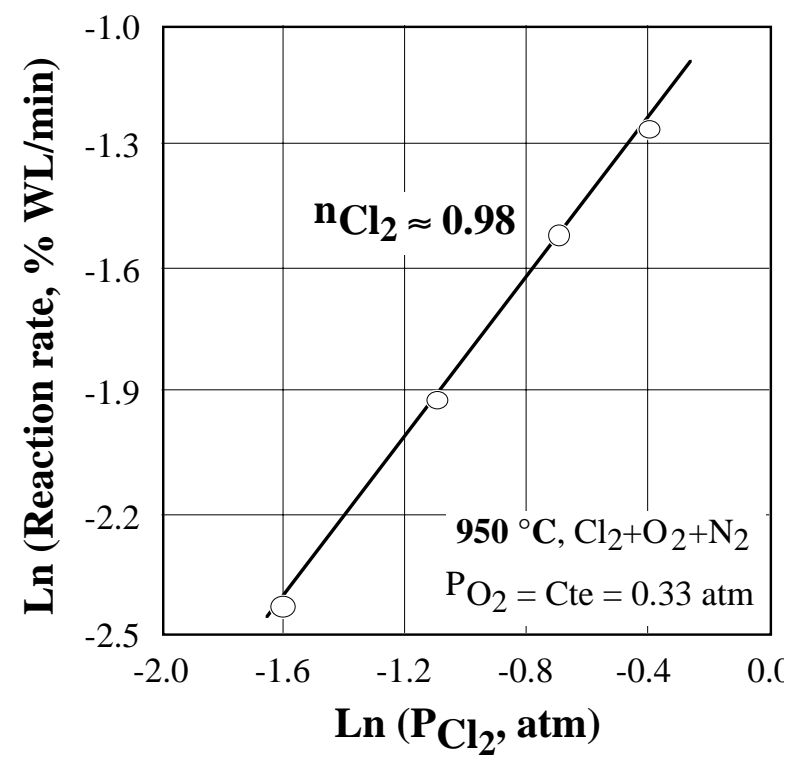

(b)

Fig. 8 : Isotherms of oxychlorination of $\mathrm{MgO}$ (a), using various $\mathrm{Cl}_{2}$ partial pressures and (b) apparent reaction order with respect to $\mathrm{Cl}_{2}$. 


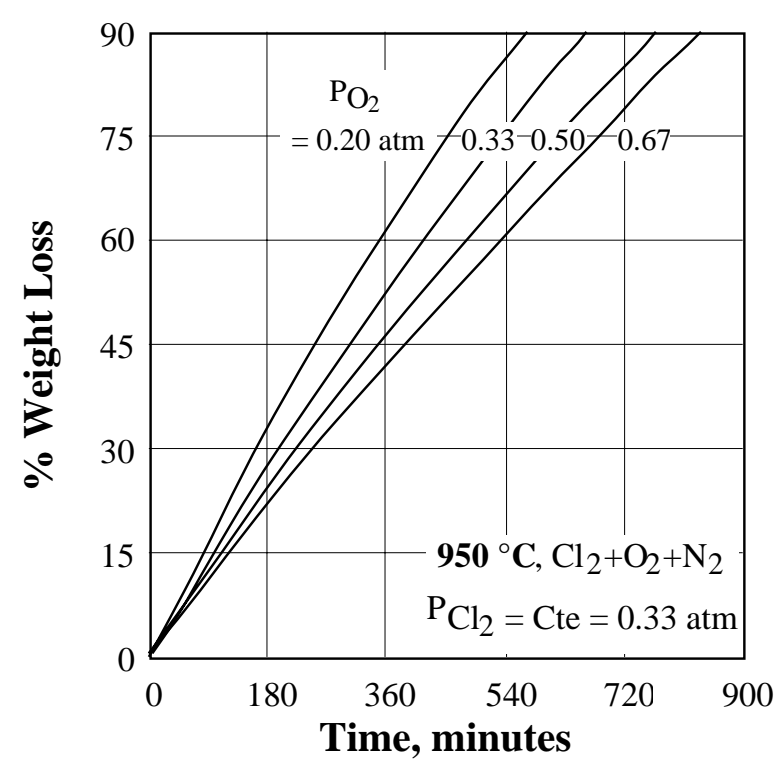

(a)

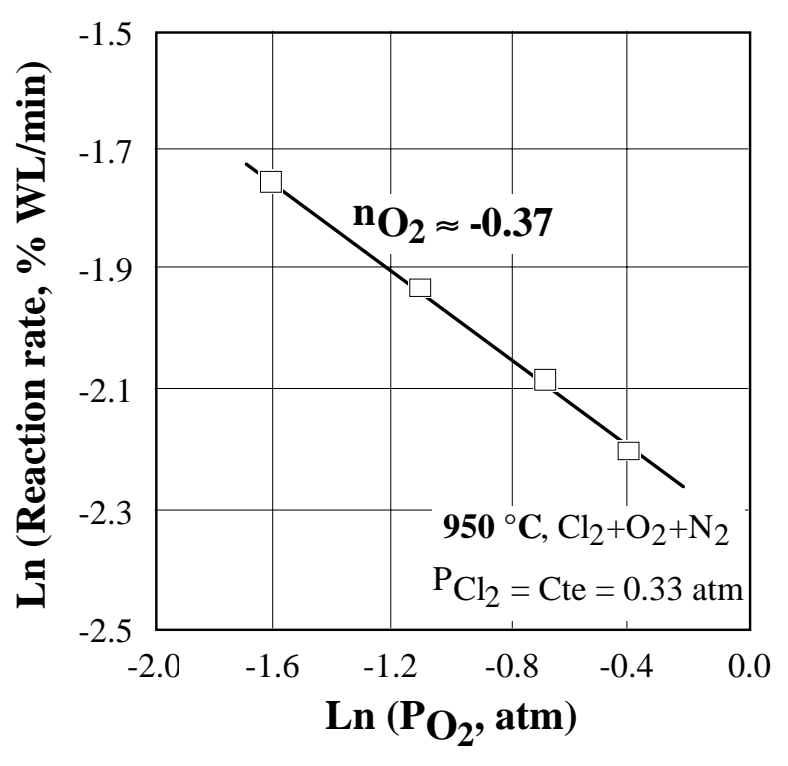

(b)

Fig. 9 : Isotherms of oxychlorination of $\mathrm{MgO}$ (a), using various $\mathrm{O}_{2}$ partial pressures and (b) apparent reaction order with respect to $\mathrm{O}_{2}$.

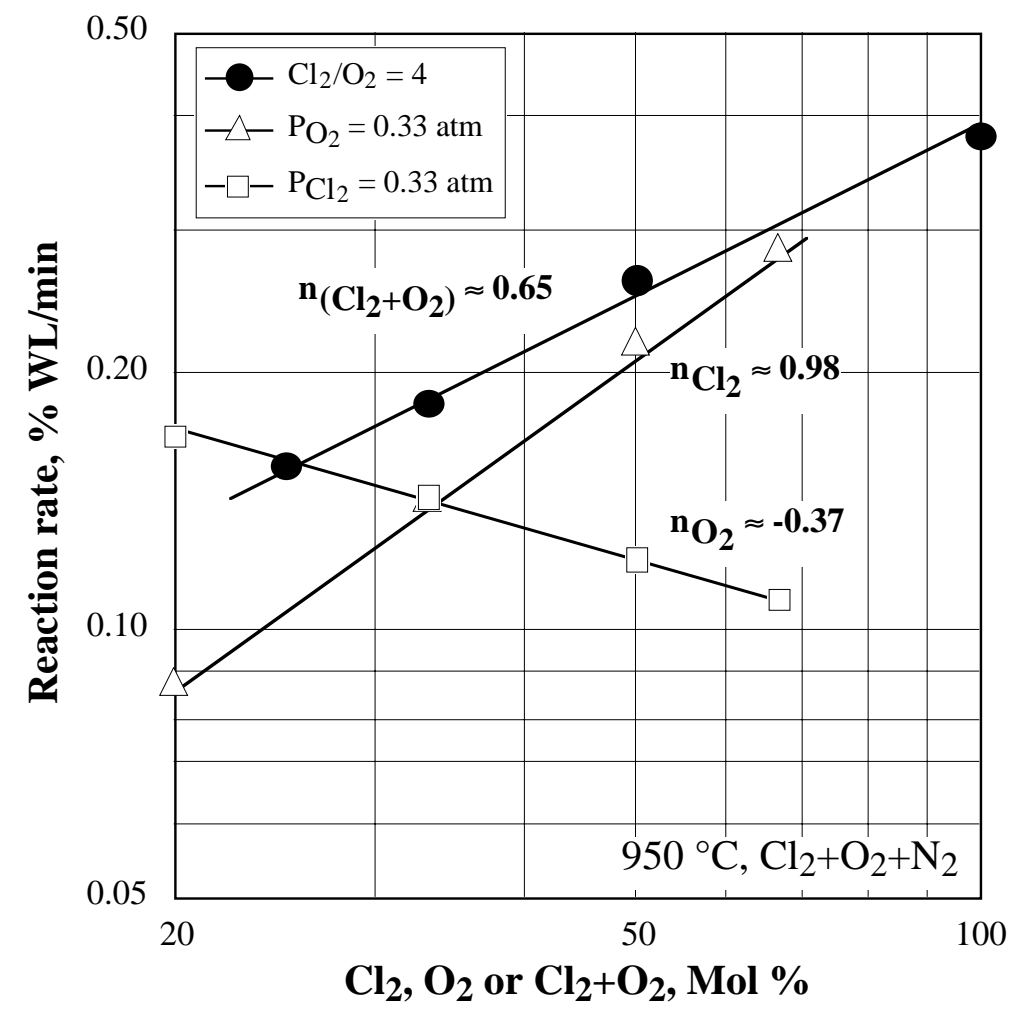

Fig. 10 : Effect of gases composition on the reaction rate of oxychlorination of $\mathrm{MgO}$. 


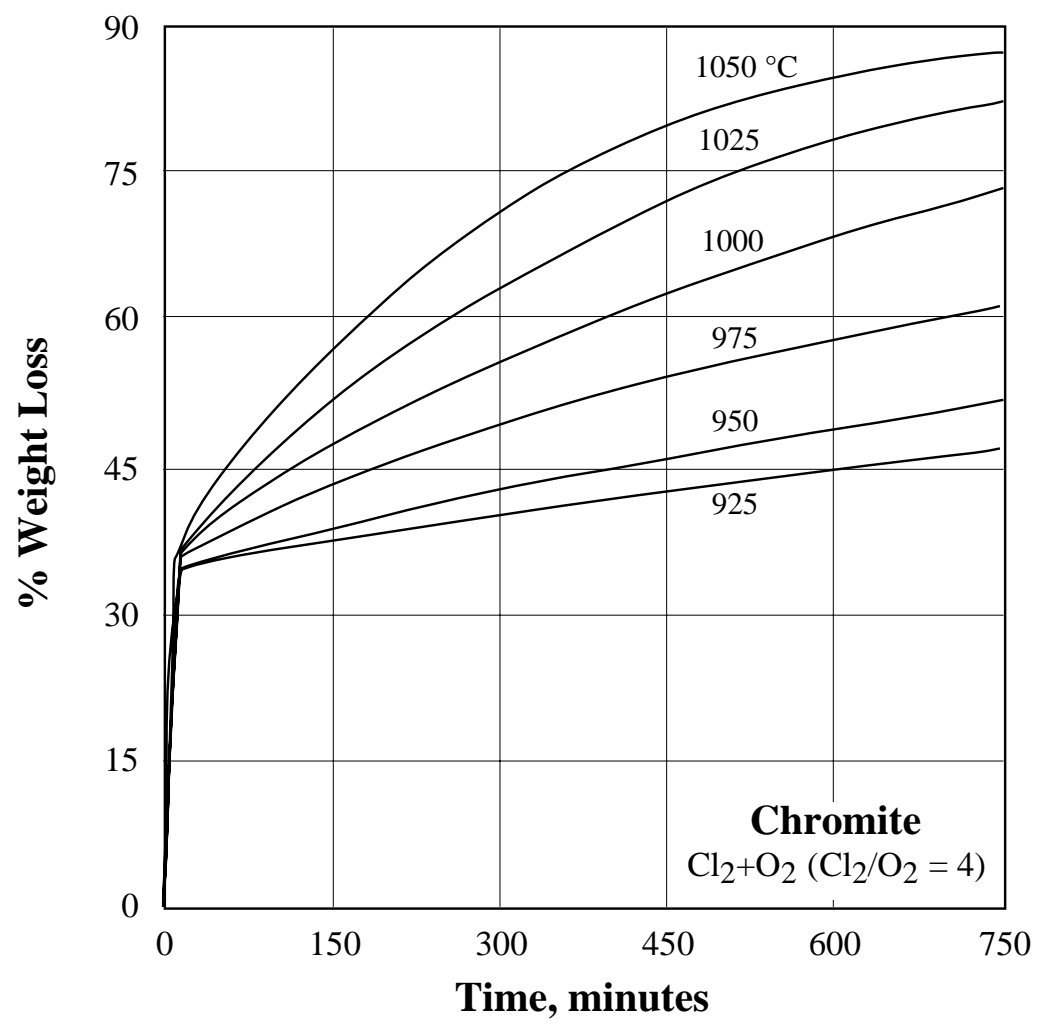

Fig. 11 : Typical isotherm plots for the oxychlorination of chromite.

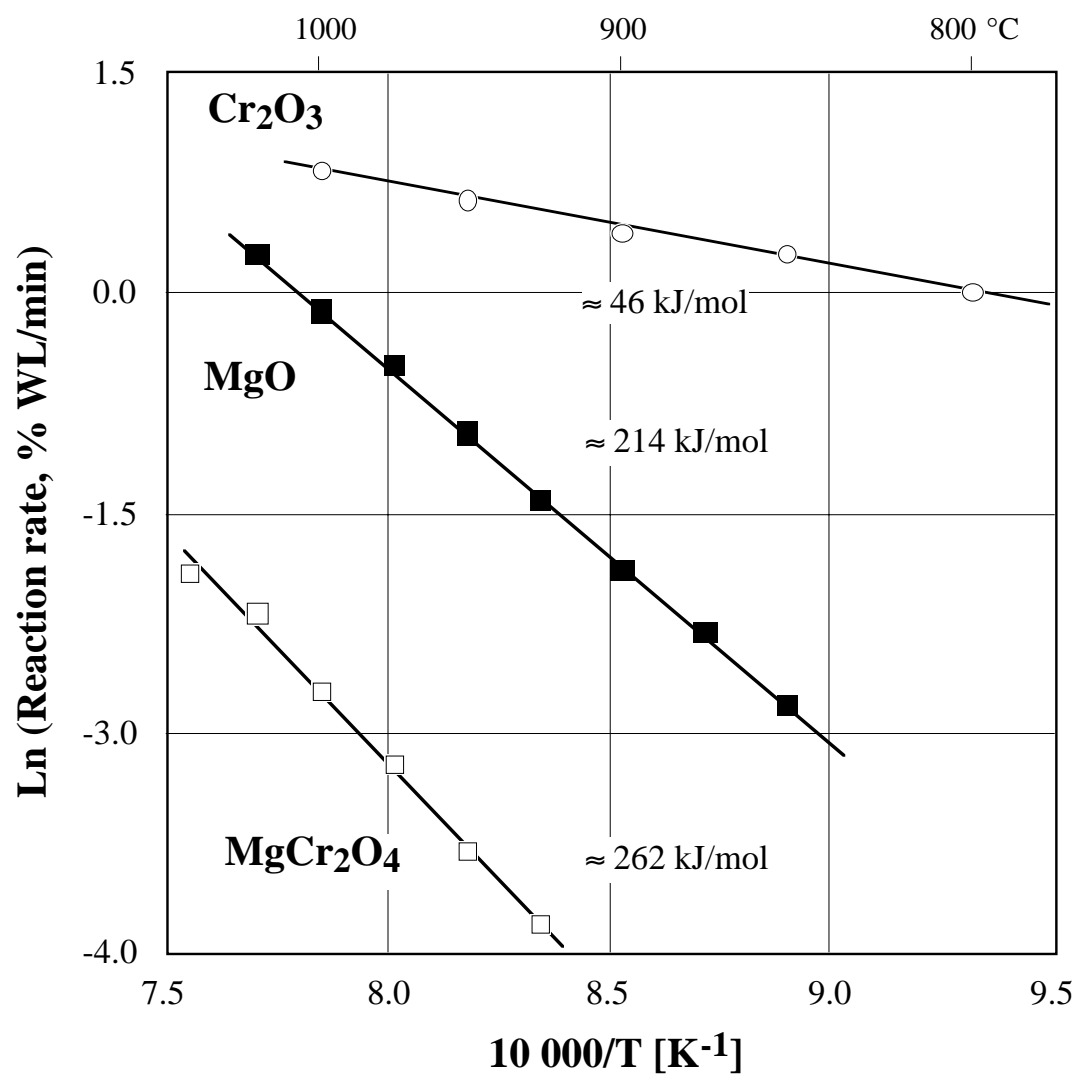

Fig. 12 : Arrhenius plots of $\mathrm{MgO}, \mathrm{Cr}_{2} \mathrm{O}_{3}{ }^{[12]}$ and $\mathrm{MgCr}_{2} \mathrm{O}_{4}{ }^{[4]}$ oxychlorination. 


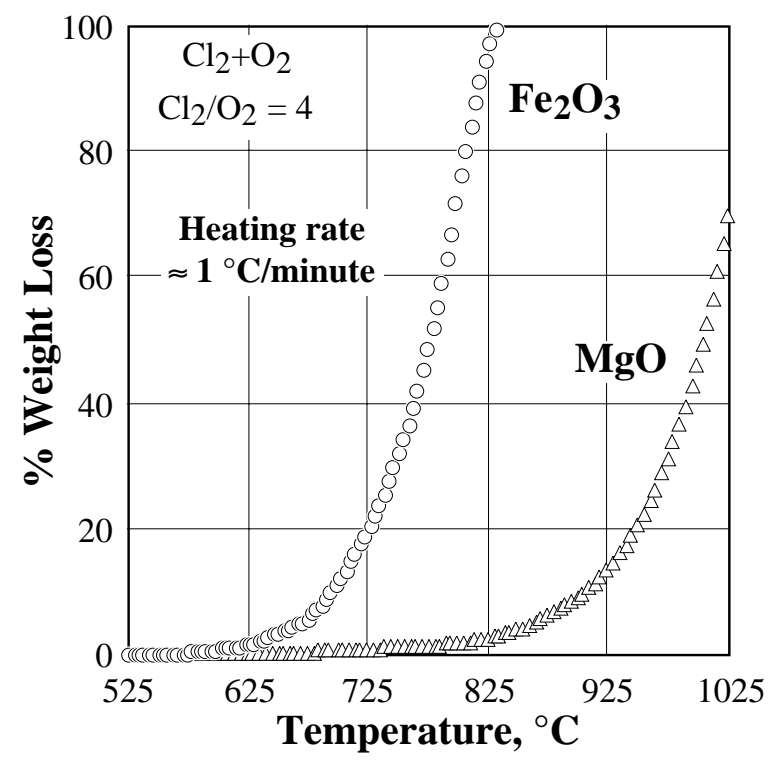

Fig. 13 : Non isothermal chlorination of $\mathrm{MgO}$ and $\mathrm{Fe}_{2} \mathrm{O}_{3}$ using $\mathrm{Cl}_{2}+\mathrm{O}_{2}$.

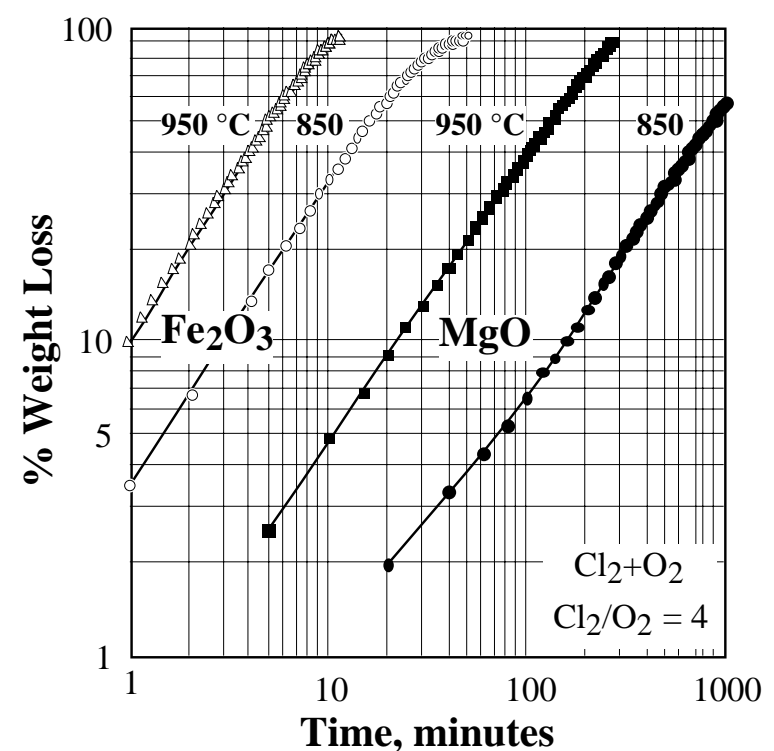

Fig. 14 : Oxychlorination of $\mathrm{MgO}$ and $\mathrm{Fe}_{2} \mathrm{O}_{3}$ at $850{ }^{\circ} \mathrm{C}$ and $950{ }^{\circ} \mathrm{C}$. 